\title{
Thyroid Hormone Resistance Syndrome
}

National Cancer Institute

\section{Source}

National Cancer Institute. Thyroid Hormone Resistance Syndrome. NCI Thesaurus. Code C85191.

A rare, autosomal recessive inherited disorder usually caused by mutations in the THRB gene. It is characterized by a defective physiological resistance to thyroid hormones, resulting in the elevation of thyroxin and triiodothyronine in the serum. 